\title{
Pregnancy in Myositis: Challenges and Pitfalls
}

\author{
Codrina Mihaela Ancuta ${ }^{1,2}$, Eugen Ancuta $^{3}$ and Rodica Marieta Chirieac ${ }^{1}$ \\ ${ }^{1}$ Department of Rheumatology; \\ ${ }^{2}$ Gr.T.Popa Center for Biomedical Research - European Center for \\ Translational Research; "Gr.T.Popa" University of Medicine and Pharmacy; \\ ${ }^{3}$ Research Department, "Cuza-Voda" Hospital Iasi
}

Romania

\section{Introduction}

Over the last decade, a lot of papers have been published by scientists and clinicians in order to disseminate their knowledge about major steps accomplished in the research of autoimmune disorders and pregnancy.

While pregnancy is delayed until later age in the majority of western countries and the incidence of autoimmune disorders, particularly rheumatic conditions, is increasing specifically in women of 25 to 40 years, patient's selection for a safe pregnancy becomes a very important concern.

It is essential to define a multidimensional concept that focus on how disease and its treatment affect pregnancy in autoimmune disorders. Based on values, goals and preferences of patients, physicians seem to be more critical in making decisions. Moreover, given the necessity to outline every physician's role in the management of pregnancy and autoimmune conditions there was a strong progress toward an interdisciplinary approach comprising rheumatologists, obstetricians, endocrinologists, immunopathologists, geneticians and neonatologists.

It was suggested formerly that women diagnosed with autoimmune diseases should avoid pregnancy due to excessive maternal and fetal risk, as autoimmunity can be reflected virtually on every aspect of reproduction (Borchers et al., 2010; Doria et al., 2006; Gordon, 2004; Peaceman \& Ramsey-Goldman, 2008). Nevertheless, recent advances in the immunopathogenesis, assessment, monitoring and specific treatment options in patients with systemic autoimmune rheumatic disorders have resulted not only in optimal disease control, improved survival as well as quality of life, but also have been reflected in better pregnancy outcomes.

As patients with autoimmune rheumatic disorders are predominantly young women at childbearing potential (between 20 and 40 years), pregnancy is a major issue with prospective interest regarding the influence of both disease and therapy on pregnancy and, conversely, the effect of pregnancy on disease outcomes (Marker-Herman \& Fisher Betz, 2010; Mecacci et al, 2007).

The physiological adaptation of the immune system to pregnancy (Th2-type response) potentially affects the course of the immune-mediated rheumatic conditions; equally, autoimmunity may compromise the fetal outcomes (Adams Waldorf \& Nelson, 2008; 
Borchers et al., 2010; Marker-Herman \& Fisher Betz, 2010). Besides, systemic autoimmune conditions may be induced as a result of maternal hormonal changes and aberrant function of the immune system during pregnancy (autoimmune rheumatic disorders associated with pregnancy) or as a consequence of materno-fetal microchimerism recognized as the longterm persistence of a small number of cells from a genetically distinct organism (autoimmune rheumatic disorders in post-partum period) (Adams Waldorf \& Nelson, 2008; Gordon, 2004; Scott, 2002).

Over the last decades, most epidemiological studies have focused on pregnancy in systemic lupus erythematosus, anti-phospholipid syndrome and rheumatoid arthritis, with special emphasis on a greater risk of relatively poor fetal outcome than in the general population, particularly with increased disease activity before conception and early in pregnancy (Doria et al., 2004; Doria et al., 2006; Gayed \& Gordon, 2007; Mecacci et al., 2007). Pregnancy can also occur in patients with rare autoimmune rheumatic diseases, specifically systemic sclerosis, polymyositis/dermatomyositis, systemic vasculitis (Wegener's granulomatosis, Churg-Strauss syndrome, polyarteritis nodosa, microscopic polyangiitis, Takayasu arteritis) and Behçet disease (Doria et al., 2004; Doria et al., 2006).

The association of myositis with pregnancy is rarely described, mainly related to average age of onset of the illness that is past reproductive age; besides, the paucity of data prevent any real assumption concerning the effects of pregnancy on idiopathic inflammatory myopathies, chiefly represented by polymyositis (PM) and dermatomyositis (DM), whether these patients find it harder to conceive or if the outcome of pregnancy is adversely affected by the myositis (Doria et al., 2004; Doria et al., 2006; Linardaki et al., 2010).

Polymyositis and dermatomyositis are heterogenous conditions characterized by a broad clinical spectrum including proximal skeletal muscle weakness, skin lesions and systemic organ involvement, particularly interstitial lung disease, biochemical and histopathological background of varying degrees of muscle inflammation. Although the exact etiology is still controversial, there is now strong evidence that autoimmunity plays a central role in both entities; endomysial autoaggressive CD8+T cells are essentially involved in PM, while perivascular B cells and TCD4+ cells in DM (Aleksza et al., 2005). Because of their clinical and laboratory similarities the term "PM/DM" will further apply when referring to both disease subtypes.

The prevalence of PM/DM is $2.4-10.7 / 100.000$ cases, women being affected more often than males (Chopra et al., 2008, Silva et al., 2003). There is a bimodal age distribution, with peaks between 10-15 years (juvenile PM/DM) and 30-60 years (adult PM/DM) (Chopra et al., 2008). Furthermore, in over $85 \%$ of patients, the disease starts after childbearing age (de Man \& Hazes, 2009), only $14 \%$ of cases presenting during reproductive period (Andreoli et al., 2010; Tincani et al., 2006). As a consequence, pregnancy in this group of myositis is uncommon (Linardaki et al., 2011).

Current concepts on immunology of normal pregnancy and specific intervention of myositis, effects of pregnancy on PM/DM and vice-versa, therapeutic options for PM/DM during pregnancy, fertility versus contraception in PM/DM will be further highlighted.

\subsection{Immunology of normal pregnancy}

Pregnancy is defined as a specific status of high levels of sex hormones and permanent crosstalk between mother and fetus, two major processes being essentially involved in 
physiological adaptation to pregnancy: (i) the modification of maternal immune system with subsequent conversion of cytokine profile and (ii) the changes of hormonal milieu throughout the course of gestation (Adams Waldorf \& Nelson, 2008; Borchers et al., 2010; Gordon C, 2004).

\subsubsection{Immune system and cytokines in normal pregnancy}

Crucial modification of the innate immune system generally occurs during normal pregnancy aiming to attain immune tolerance toward paternal antigens expressed by fetal cells (considered as a semi-allogenic graft) (Kelling \& Oswald, 2009; Tincani et al., 2006; Zen et al., 2010); furthermore, both local (feto-maternal interface) and systemic changes are directly guided by increasing levels of sex steroids (Kelling \& Oswald, 2009; Zen et al., 2010). The cytokine network in pregnancy is conflicting even before any debate of concurrent rheumatic disease (Kelling \& Oswald, 2009). It is widely accepted that maternal immune system modulates the cytokine pattern, promoting increased Th2-type cytokines production and decreased Th1-type response with subsequent Th2 polarisation that is crucial for a positive pregnancy outcome (Tincani et al., 2006; Zen et al., 2010). Moreover, it is actually well known that not only cytokine concentrations, but also soluble cytokine receptors change throughout the stages of normal pregnancy (Zen et al., 2010).

As a matter of fact, Th2-type background comprises key mediators with anti-inflammatory properties such as IL-4 and IL-10, IL-3, IL-5, IL-13 and Gm-CSF, classically accepted to enhance humoral immunity and to induce antibody production, being also involved in advancing placental growth and preventing fetal rejection (Raghupathy \& Kalinka, 2008; Tincani et al, 2006; Zen et al., 2010). On the other hand, Th1-type cytokines such as TNF-a, IFN- $\gamma$, TNF- $\beta$, IL-1 $\beta$, IL- 6 and IL-2 secreted by Th1 cells are involved in cell-mediated immunity and inflammatory reactions and appear to have a primary role in early pregnancy, including embryo implantation and placental development (Raghupathy \& Kalinka, 2008; Zen et al., 2010). In particular, although serum level of most Th1 cytokines significantly decreases in the third trimester, TNF-a level seems to remain stable in addition to increase in soluble TNF- $\alpha$ receptor, acting in order to protect from adverse outcomes such as preeclampsia, intrauterine growth retardation and pathological labor (Zen et al., 2010).

\subsubsection{Hormones in normal pregnancy}

Profound changes of the hormonal state take place during pregnancy (Østensen et al., 2011). Therefore, the Th1/Th2 shift is the result of a progressive increase in progesterone and estrogens levels during pregnancy driven by feto-placental unit, with a peak level accomplished in the third trimester of gestation (Kelling \& Oswald, 2009; Zen et al., 2010).

Clearly, there have been described major differences in estrogen control on pro- and antiinflammatory pathways in different immune-inflammatory cells (particularly T-cells, B-cells and activated monocytes). Thus, at high levels commonly encountered during gestation (3 to 8 times to baseline), estrogens seem mainly to suppress Th1-cytokines, particularly TNFa, and to stimulate Th2-mediated immunological responses as well as antibody production (Cutulo et al., 2008; Cutulo et al., 2008; Tincani et al., 2006). On the other hand, the dynamics of progesterone, a potent immunomodulator hormone primarily secreted by placenta during the first 6-8 weeks of gestation, shows a spectacular increase (4 to 6 times), while deoxycorticosterone, one of its metabolites, reaches 1000 times higher concentration than in non-pregnant state; furthermore, progesterone inhibits Th1-type cytokine synthesis from $\mathrm{T}$ cells and induces Th2 cytokine, leading to a stimulation of humoral immunity (Zen et al., 2010). 
Interestingly, temporary aberrant levels of free steroid hormones (glucocorticoids), gonadotrophin-releasing hormone $(\mathrm{GnRH})$ and prolactin may also play a role in pregnancy and postpartum period, inducing changes of the immunocompetent cells (Kelling \& Oswald, 2009; Zen et al., 2010). In addition, prolactin up-regulates Th-1-derived cytokines, including IL-12, IL-1, IL-6 and IFN- $\gamma$, modulating equally immune and inflammatory responses (Zen et al., 2010).

\subsection{PM/DM in pregnancy}

It is now much better established that the particular hormonal, biochemical and immunological interference in pregnancy may shape the course of autoimmune rheumatic diseases, including PM/DM (Cutulo et al., 2008; Cutulo et al., 2008). Furthermore, the mutual impact between the immune system and endocrine axis could explain why both of them may be affected by autoimmune diseases (Zen et al., 2010). As a result, the previous accepted Th2-Th1 paradigm is still considered the background of the disease flare during pregnancy and the improvement after delivery in Th2-mediated systemic autoimmune diseases. Several studies strongly support the link between the underlying pathological process and the course of such illness during gestation (Cutulo et al., 2008; Cutulo et al., 2008): Th1 predominant diseases like rheumatoid arthritis usually improve, with potential exacerbation after delivery (Cutulo et al., 2008; Cutulo et al., 2008; Váncsa et al., 2007); conversely, Th2-mediated disorders like systemic lupus erythematosus tend to remain relatively unchanged or, primarily, to worsen (Tincani et al., 2006).

Furthermore, the relationship between pregnancy and pathophysiological mechanisms of PM/DM is also unclear (Váncsa et al., 2007), due to extremely limited data. Cytokines and chemokines are essential players in the initiation and progression of the PM/DM, current evidence promoting the predominance of Th1-mediated immunity in different myositis subsets (Aleksza et al., 2005; de Paepe et al., 2009; Szodoray et al., 2010). It has been recently suggested, particularly for patients diagnosed with DM, that the onset of the disease may be triggered by the raise in serum estrogen concentration with subsequent effects on TNF- $\mathrm{a}$ synthesis as described in early pregnancy (Linardaki et al., 2011). The central role of TNF- $\alpha$ cytokine in the pathogenesis of DM is largely accepted; not only up-regulation of TNF- $\alpha$ expression in inflammatory and endothelial cells from muscle specimens and high soluble type 1 and 2 TNF-receptors, but also over-expression of TNF- $\alpha$ in regenerating muscle fibers have been identified (Aleksza et al., 2005; de Paepe et al., 2009; Linardaki et al., 2011).

Moreover, aberrant immunologic response caused by the presence of fetal cells in the maternal circulation and/or certain viral infections (Coxsackie viruses, Parvoviruses, Enteroviruses, Retroviruses, in particular Human T-lymphotropic virus and HIV) with subsequent impairment of humoral immune responses have also been proposed for the pathogenesis of pregnancy-associated DM (Linardaki et al., 2011).

Unfortunately, only a small number of reports on pregnancy outcomes in women with rare autoimmune rheumatic disorders such as PM/DM are yet available. The spectrum of possible adverse effects in pregnant women with myositis varies largely from intrauterine growth retardation and preterm delivery to increase frequency of fetal loss (spontaneous abortion, miscarriage, fetal death), and, finally, even to autoimmune disease in offspring (Borchers et al., 2010; Mecacci et al., 2007).

On the other hand, given the relationship between PM/DM and pregnancy three specific categories can be individualized: (i) flare-up/exacerbation of preexisting disease during gestation, (ii) onset of new PM/DM throughout the course of pregnancy, and (iii) postpartum flare or onset of myositis (Silva et al., 2003). 
Fetal and maternal prognosis in patients diagnosed with myositis will be further discussed based on disease subsets (juvenile versus adult PM/DM), disease onset (pre-existing versus new-onset pregnancy-associated) and disease status (inactive versus active type).

\section{Effects of PM/DM on pregnancy outcomes}

As a matter of fact, pregnancy complicating myositis is a rare event, as the average age of onset for the disease is past reproductive age (Doria et al., 2006). However, similar to other autoimmune rheumatic diseases, it should be considered as a high-risk population if previous pregnancy complications, underlying systemic manifestation of myositis in target organs and flare of rheumatic illness are present (Borchers et al., 2010; Doria et al., 2006).

Overall, the course of pregnancy and fetal prognosis are considered to reflect the level of maternal disease status, paralleling the activity of myositis (Linardaki et al., 2011; Silva et al., 2003); the more active the myositis during the pregnancy, the greater the chance of fetal loss (Linardaki et al., 2011).

\subsection{Pre-existing PM/DM}

Better pregnancy outcomes in childhood onset versus adult PM/DM.

Since the majority of pregnancies reported in juvenile subset of PM/DM developed in an inactive phase of the disease, fetal outcome is favorable (de Man \& Hazes, 2009; Silva et al., 2003) Moreover, up to $70 \%$ of cases presented with full term birth. Although perinatal pathology was defined, major adverse events including fetal death and abortion were rarely observed (de Man \& Hazes, 2009; Tincani et al., 2006).

On the other hand, in patients with adult onset disease before pregnancy, fetal prognosis is worse, only half of women presenting full term deliveries (de Man \& Hazes, 2009; Silva et al., 2003; Tincani et al., 2006).

Better pregnancy outcomes in inactive versus active PM/DM.

Pregnancy occurring during quiescent phase of pre-existing disease, controlled with or without low dose corticosteroids, is characterized by minimal fetal risk (Váncsa et al., 2007). Indeed, despite the fact that women with myositis who get pregnant must be considered as having a relatively high risk of developing complications, the outcome is better when the disease is inactive (Andreoli et al., 2010; Chopra et al., 2008; de Man \& Hazes, 2009; Silva et al., 2003; Tincani et al., 2006). Furthermore, if the disease is maintaining inactive during pregnancy, excellent fetal outcomes with high percentage of normal deliveries have been mentioned (Andreoli et al, 2010; de Man \& Hazes, 2009; Silva et al., 2003; Tincani et al., 2006; Váncsa et al., 2007). Since optimal pregnancy success can be anticipated if the diseases in remission before conception (Silva et al., 2003; Váncsa et al., 2007), up to 55\% cases present with perinatal morbidity and mortality, mainly fetal growth restriction (Chopra et al, 2008).

Conversely, pregnancy in active PM/DM should be considered at high-risk for both the mother and the baby meaning risk for intrauterine retardation, high rate of pregnancy loss (death) or prematurity (Clowse, 2010; de Man \& Hazes, 2009; Mecacci et al, 2007; Silva et al., 2003; Váncsa et al., 2007).

As it appear that the major risk is related to active disease, significant differences in pregnancy course and outcomes in active versus inactive PM/DM subsets have been suggested by most authors: rates of full term birth ( $72 \%$ versus $47 \%$, respectively), intrauterine fetal death $(43 \%$ versus $13.6 \%$, respectively) and intrauterine growth 
retardation/premature delivery (33\% versus 13.6\%, respectively) (Chopra et al, 2008; de Man \& Hazes, 2009; Silva et al., 2003; Tincani et al, 2006; Váncsa et al., 2007). However, some papers advanced the idea that the proportion of fetal loss is quite similar in active versus inactive myositis, supporting the key role of monitoring in order to detect pregnancy complications (Silva et al., 2003).

Worse pregnancy outcomes in PM/DM exacerbation during pregnancy.

About a quarter of childhood onset PM/DM subset and up to 16\% of adult PM/DM (de Man \& Hazes, 2009) flared-up during pregnancy; the exacerbation of pre-existent disease account also for a significantly worse pregnancy outcome (Tincani et al., 2006). On the other hand, no sign of autoimmune disease has been observed in offspring (Tincani et al., 2006).

\subsection{New-onset PM/DM}

Worse pregnancy outcomes in new-onset versus pre-existing PM/DM

$\mathrm{PM} / \mathrm{DM}$ starting during pregnancy or new-onset disease is a rare event, commonly reported in the first trimester of gestation (de Man \& Hazes, 2009; Tincani et al, 2006; Váncsa et al., 2007). The risk of both maternal and fetal pathology is particularly high, over $50 \%$ fetal death (spontaneous abortion, intrauterine death, fetal loss) and high rate of prematurity being classically seen (Váncsa et al., 2007; de Man \& Hazes, 2009).

Worse pregnancy outcome in PM/DM starting during early versus late pregnancy

It is now evident that pregnancy outcome is particularly poor with disease onset early in the gestation compared to the second or third trimester, when the fetal prognosis is usually good (Tincani et al, 2006; Váncsa et al., 2007; Chopra et al, 2008; de Man \& Hazes, 2009). More recent cases had a good outcome, probably because active new-onset disease during pregnancy could be controlled by increasing corticosteroids, remissive agents, even therapeutic abortion in life-threatening cases to decrease the maternal mortality (Váncsa et al., 2007).

\section{Effects of pregnancy on PM/DM outcomes}

Although PM/DM does not seem to be particularly influenced by pregnancy, four main types could be identified based on clinical course in relation to gestation: (i) inactive-stable disease, (ii) relapsing disease, (iii) new-onset disease and (iv) either postpartum onset or flare of the disease (de Man \& Hazes, 2009; Váncsa et al., 2007). The evolution of myositis is considered to be stable, if the patient remains free of clinical and laboratory disease activity during gestation, while a relapse is defined as disease exacerbation or reactivation because of the increase in serum muscle enzymes (creatine kinase and/or lactic dehydrogenase), typical clinical signs of proximal muscle involvement (weakness, pain) with or without characteristic skin signs (heliotrope rash, Gottron's papules). Consequently, maternal prognosis appears to be directly linked to disease course in pregnancy (de Man \& Hazes, 2009; Silva et al., 2003; Tincani et al, 2006; Váncsa et al., 2007).

No increase in disease activity has been noted in nearly $90 \%$ of the pregnant women with adult PM/DM subset (de Man \& Hazes, 2009; Váncsa et al., 2007). Moreover, the chance of juvenile disease to remain stable during gestation varies between $60 \%$ and $75 \%$, positive maternal outcomes being typically documented (de Man \& Hazes, 2009; Tincani et al, 2006; Váncsa et al., 2007). Finally, the overall relapse rate on corticosteroid therapy is $16 \%$ during pregnancy in the inactive phase of the myositis (Váncsa et al., 2007).

Although new-onset myositis during pregnancy is uncommon, patients typically develop very active therapy-resistant disease, with subsequent interference of both pregnancy and 
labor (de Man \& Hazes, 2009; Tincani et al, 2006; Váncsa et al., 2007) and worse maternal prognosis.

Furthermore, postpartum onset PM/DM have been recognized in several cases, suggesting that the post-partum period ( 1 to 3 months) may be a trigger for the development of myositis as a consequence of exposure to fetal antigens (Silva et al., 2003).

A summary of fetal and maternal outcomes based on PM/DM subset and disease activity is shown in Table 1.

Interestingly, recurrence in subsequent pregnancies is rarely seen (Pasrija et al., 2005); variable maternal and fetus outcomes in the same women but with different pregnancies could support the intervention of autoimmune pathology and consequently utero-placental involvement, even when disease is in remission (Chopra et al, 2008).

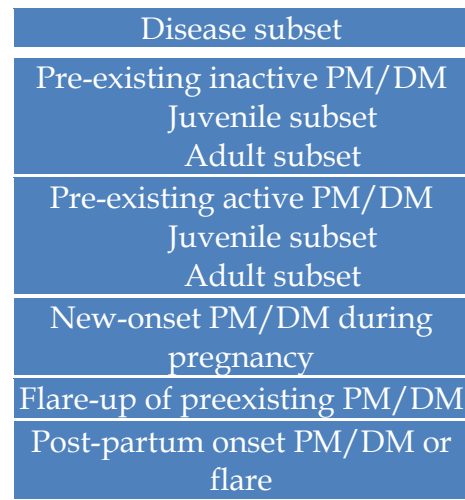

\begin{tabular}{|c|c|}
\hline $\begin{array}{c}\text { Fetal prognosis } \\
\begin{array}{c}\text { Favorable } \\
\text { Moderate to Negative }\end{array}\end{array}$ & $\begin{array}{c}\text { Maternal prognosis } \\
\text { Low to moderate risk for flare-up }\end{array}$ \\
\hline $\begin{array}{c}\text { Negative } \\
\text { Negative }\end{array}$ & $\begin{array}{c}\text { Negative outcomes } \\
\text { Negative outcomes }\end{array}$ \\
\hline Negative & High risk for worse outcomes \\
\hline Negative & High risk for worse outcomes \\
\hline Not applicable & Moderate risk for worse outcomes \\
\hline
\end{tabular}

Table 1. Maternal and fetal outcome based on disease subset and activity.

\section{Treatment options for PM/DM in pregnancy}

Management of PM/DM in pregnancy is often a challenge even face to advancing knowledge in the immunopathogenesis of myositis and pregnancy. Main concerns are related to anti-rheumatic drugs use taking into account the teratogenic potential, adverse outcomes on fetal growth and development, as well as potential harmful effects on the offspring (Motta et al., 2008; Østensen, 2004; Østensen et al., 2005; Østensen et al., 2008; Østensen et al, 2011). Moreover, special considerations should be made on their effect on disease activity and maternal side effects.

The most important reasons for treatment of PM/DM during gestation are: (i) to prevent a disease flare-up, (ii) to control disease activity and (iii) to assure a good pregnancy outcome (Chopra et al, 2008; Lockshin, 2006; Østensen, 2004; Østensen et al., 2005; Østensen et al., 2008; Østensen et al., 2011).

As in non-pregnant PM/DM, the available medication for treating myositis in pregnancy can be divided in two main categories: (i) first-line therapy meaning steroids and (ii) secondline therapy meaning Disease Modifying Anti-Rheumatic Drugs (DMARDs) and intravenous immunoglobulins (IVIG) (Chopra et al, 2008; Østensen et al., 2004; Pasrija et al., 2005).

Extensive critical reviews of the current evidence and consensus regarding the use of antirheumatic drugs in pregnancy and lactation have already been published (Keeling \& 
Oswald, 2009; Østensen, 2004; Østensen et al., 2008; Saar et al., 2006). Even if the differences between various stages of gestation and between experimental and human pregnancies are not listed, clinical experience has shown that certain drugs, if properly monitored, can be maintained throughout gestation, resulting in better fetal outcome and better control of the disease in postpartum period (Keeling \& Oswald, 2009; Motta et al., 2008; Østensen, 2004; Østensen et al., 2008). Pros and contra for their use in pregnant women diagnosed with PM/DM will be further discussed and summarized in table 2.

\subsection{Corticosteroids}

As for other autoimmune rheumatic disorders, patients with myositis require aggressive short-term corticosteroids to promptly suppress disease activity (Kelling \& Oswald, 2009; Østensen, 2004; Østensen et al., 2005; Østensen et al., 2008; Østensen et al., 2011). While medium to high doses of prednisone and prednisolone are widely accepted as first-line therapy in pregnant women with myositis, dexamethasone and betamethasone are commonly reserved for fetal treatment (Kelling \& Oswald, 2009; Linardaki et al., 2011; Østensen, 2004; Østensen et al., 2005; Østensen et al., 2008; Østensen et al, 2011).

\begin{tabular}{|c|c|c|c|c|}
\hline Drug & $\begin{array}{l}\text { FDA } \\
\text { category* }\end{array}$ & Concerns & Clinical signification & Breastfeeding \\
\hline Corticosteroids & $\mathrm{C}$ & $\begin{array}{l}\text { Cleft palate } \\
\text { Premature } \\
\text { rupture of } \\
\text { membranes } \\
\text { Gestational } \\
\text { diabetes mellitus } \\
\text { Hypertension } \\
\text { (conflicting } \\
\text { reports) }\end{array}$ & $\begin{array}{l}\text { Safe }<10 \mathrm{mg} / \text { day } \\
\text { Caution }>20 \\
\mathrm{mg} / \text { day }\end{array}$ & $\begin{array}{l}\text { Safe; delaying feed } \\
\text { by } 4 \text { hours with }>20 \\
\text { mg daily }\end{array}$ \\
\hline $\begin{array}{l}\text { (Hydroxy)- } \\
\text { chloroquine }\end{array}$ & $\mathrm{C}$ & $\begin{array}{l}\text { Fetal eye-ear } \\
\text { effects } \\
\text { (theoretical) } \\
\text { No increased risk } \\
\text { of malformations }\end{array}$ & $\begin{array}{l}\text { Commonly used in } \\
\text { pregnancy in } \\
\text { autoimmune } \\
\text { rheumatic disorders }\end{array}$ & $\begin{array}{l}\text { Safe; small amount } \\
\text { in breast milk }(2 \%)\end{array}$ \\
\hline Azathioprine & $\mathrm{D}$ & $\begin{array}{l}\text { Intrauterine } \\
\text { growth restriction } \\
\text { Prematurity }\end{array}$ & $\begin{array}{l}\text { Commonly used, } \\
\text { possible safe }\end{array}$ & Probable safe \\
\hline $\begin{array}{l}\text { Intravenous } \\
\text { immune- } \\
\text { globulins }\end{array}$ & $\mathrm{C}$ & & Few case reports & Probable safe \\
\hline Methotrexate & X & $\begin{array}{l}\text { Teratogenicity, } \\
\text { malformations, } \\
\text { abortion }\end{array}$ & $\begin{array}{l}\text { Discontinue } 3-4 \\
\text { months prior to } \\
\text { conception }\end{array}$ & $\begin{array}{l}\text { Excreted in breast } \\
\text { milk; not safe }\end{array}$ \\
\hline
\end{tabular}

*FDA category C (risk cannot be ruled out); D (positive evidence of risk); $\mathrm{X}$ (contraindicated in pregnancy)

Table 2. Anti-rheumatic drugs and their Food and Drug Administration (FDA) classifications in pregnancy and lactation in women with PM/DM. 
Corticosteroids are essentially used in pregnancy myositis for dual reason, to control disease and to support pulmonary fetal maturity, but they are Food and Drug Adminstration (FDA) category C (Kelling \& Oswald, 2009; Pasrija et al., 2005). It is well known that systemic steroids cross the placenta and the amounts vary according to steroid type, prednisolones crossing in low concentrations while dexamethasone and betamethasone in larger ones (Kelling \& Oswald, 2009). Since placental enzymes such as 11-beta-hydroxylases partially inactivate all corticosteroids, with further decrease in steroid concentration in the fetal blood to $5-10 \%$ of the administered dose, the fetal risk appears to be very low at or below 15 mg/day (Linardaki et al., 2011; Østensen, 2004; Østensen et al., 2005; Østensen et al., 2008; Østensen et al., 2011, Silva et al., 2003;). Conversely, long-term use of medium to high doses, particularly during late pregnancy, may result in toxicity (Linardaki et al., 2011). Infrequently reported side effects consist of significant increase in cleft palate with first trimester exposure, high risk of premature rupture of membranes and preterm deliveries with more than $20 \mathrm{mg}$ prednisone daily in late pregnancy, growth retardation, gestational diabetes, neonatal cataracts, adrenal suppression in neonates and high risk for infection (Kelling \& Oswald, 2009; Linardaki et al., 2011; Østensen, 2004; Østensen et al., 2005; Østensen et al., 2008; Østensen et al., 2011).

The risk-benefit ratio must be considered on a case-by-case basis. Those patients on steroids at the time of delivery require additional stress doses indicated for labor and delivery to prevent acute adrenal insufficiency (Østensen, 2004; Østensen et al., 2008; Silva et al., 2003;). Although small amounts of steroids are also excreted in milk, breastfeeding is considered safe; doses over $20 \mathrm{mg}$ daily should delay the next breastfeed with at least 4 hours (Kelling \& Oswald, 2009).

\subsection{Conventional DMARDs}

Severe active potentially life-threatening cases of new-onset PM/DM and flare-up of preexisting PM/DM are perhaps the only indications for the use of chemotherapeutic agents for the management of myositis during pregnancy (Østensen, 2004; Østensen et al., 2005; Østensen et al., 2008; Østensen et al., 2011; Silva et al., 2003). Immunosuppressives should be added if corticosteroids are not able to control the disease or as steroid-sparing drugs; the clinical use of these medications differs according to their FDA categories (Kelling \& Oswald, 2009).

Azathioprine, an anti-neoplastic agent considered FDA category D for pregnancy, is safe during gestation and has been administered in pregnant women with myositis at 1.5-2 $\mathrm{mg} / \mathrm{kg} /$ day. Case reports have shown increased rates of intrauterine growth restriction and prematurity, occasionally suppression of the fetal bone marrow (Linardaki et al., 2011; Østensen, 2004; Pasrija et al., 2005).

Cloroquine and hydroxychloroquine are antimalarials commonly used for DM patients; although they are FDA category $\mathrm{C}$, the major concern includes theoretical risks of fetal oculo-toxicity or oto-toxicity and developmental abnormalities as both drugs crosses the placenta and accumulates preferentially in melanin-containing structures such as fetal uveal tract and inner ear (Kelling \& Oswald, 2009; Østensen, 2004; Østensen et al., 2005; Østensen et al., 2008; Pasrija et al., 2005). Despite small amounts of excretion in breast milk (up to $2 \%$ ), it is safe in breastfeeding (Kelling \& Oswald, 2009).

Methotrexate and cyclophosphamide are contraindicated during pregnancy and lactation because of potential teratogenicity, mutagenicity and embryotoxicity (Kelling \& Oswald, 2009; 
Østensen, 2004; Pasrija et al., 2005; Saar et al., 2006). Methotrexate, a FDA category X drug, should be prescribed in fertile women only under safe contraception. Moreover, since active metabolites persist for about two months after discontinuation of therapy, conception should be delayed up to three months after withdrawal, while folate supplementation should be continued throughout gestation. Although indicated in the management of different forms of myositis, cyclophosphamide is a human teratogen; safe contraception is necessary in with women with childbearing potential and conception should be delayed until three months after drug discontinuation (Østensen, 2004; Pasrija et al., 2005).

\subsection{Intravenous Immunoglubulin G}

Finally, the intravenous administration of high doses of IgG (IVIG) seems to be an attractive alternative for pregnancy-associated DM given its efficacy, corticosteroid-sparing effect and the reduced risk of steroid-related side effects (Linardaki et al., 2011; Pasrija et al., 2005). While the benefits of IVIG are widely accepted in a variety of autoimmune disorders including DM in adults, uncontrolled observations suggest that it may also be effective in up to $70 \%$ of patients with PM (Linardaki et al., 2011).

Although the exact mechanism of action of IVIG in DM is not accurately defined, it is believed to be linked to suppression of pathogenic cytokines, modulation of pathogenic autoantibodies and $\mathrm{Fc}$ receptor blockade, with subsequent adjustment of $\mathrm{T}$ cell function. Additionally, the complications of IVIG therapy are relatively mild and consist primarily of non-anaphylactic reactions, such as fever, chills and back pain, aseptic meningitis in up to $10 \%$ of patients, acute tubular necrosis basically in patients with preexisting renal disease and, rarely, thrombo-embolic events due to increased serum viscosity (Linardaki et al., 2011).

Interestingly, the benefits of IVIG have been considered in a small number of DM presenting during pregnancy (Linardaki et al., 2011); IVIG given either as monotherapy or in combination with corticosteroids resulted in disease remission in all cases, with no maternal or fetal complications and positive fetal outcomes (Linardaki et al., 2011). However, there are still unanswered questions regarding the optimal therapeutic protocol (safest effective dose, frequency of administration, discontinuation before or maintenance after delivery) (de Man \& Hazes, 2009; Linardaki et al., 2011).

Generally, a good fetal outcome can be expected if the maternal disease remains inactive during pregnancy (Chopra et al, 2008). Besides, it appears that the disease activity in active either pre-existing or new-onset cases could be controlled by increasing the corticosteroid dose (Chopra et al, 2008, Váncsa et al., 2007) and/or by adding remissive drugs such as azathioprine and hydroxicloroquine. Moreover, intravenous immunoglobulins should be considered in non-responders or, as recently suggested, monthly in order to prevent abortion (Váncsa et al., 2007, Linardaki et al., 2011). Therapeutic abortion has to be considered in life-threatening cases to decrease the maternal mortality (Linardaki et al., 2011), while the expected postpartum disease flare may be avoided by restarting medications soon after delivery.

\section{Fertility and contraception in PM/DM}

It is actually widely recognized that fertility is generally maintained in patients with rheumatic autoimmune conditions (Clowse, 2010). Furthermore, the rate of nulliparity 
among women with myositis is comparable with the general population (about 12\%) (Silva et al., 2003). Although it has been suggested that fertility rates are significantly different before and after the onset of PM/DM, the late age of onset and the use of contraceptives exclude a specific evaluation of the influence of the disease on fertility (Costa et al., 2008; Clowse, 2010).

Contraception is an important issue in all autoimmune rheumatologic disorders since active disease and potential use of teratogenic anti-rheumatic drugs may result in adverse pregnancy outcomes (Costa et al., 2008; Clowse, 2010).

Three main contraceptive options are available, being applicable also in women diagnosed with PM/DM, including

i. barrier methods (condoms, diaphragm, with or without spermicides),

ii. progestin-only methods (daily pills, every 3-months injections, a 3-year implant, emergency contraception) and

iii. (progesterone-containing) intrauterine devices (IUDs) (Clowse, 2010).

It is widely accepted that progesterone, either systemic or locally released, does not worsen the rheumatologic illness as they do not increase immune activity or the risk for thrombosis. Furthermore, emergency contraception with levonorgestrel which is prescribed to prevent conception following unprotected intercourse and is responsible for the inhibition of ovulation, prevention of fertilization and prevention of implantation by modifying the endometrium, is known to be safe for patients with autoimmune rheumatic disorders. In addition, local effects described in progesterone-containing IUD comprise induction of atrophy of the uterine lining, impairment transport of sexual cell and decreased the frequency of ovulation, being also safe in autoimmune rheumatic pathology (Costa et al., 2008; Clowse, 2010).

Finally, it is well known that the combination of oestrogen and progestatives is commonly used to reduce certain side effects related to progesterone administration; as a consequence, a high oestradiol level (nearly $200 \mathrm{pg} \mathrm{ml}^{-1}$ ) is constantly maintained, advancing thrombosis in susceptible individuals (Clowse, 2010). Therefore, oestrogen-based contraception is thought to be risky in systemic lupus erythematosus, with no evidence for PM/DM (Costa et al., 2008; Clowse, 2010).

\section{Recommendations for pregnancy in PM/DM}

Several general recommendations targeting maternal, fetal and neonatal complications have been already proposed for more prevalent autoimmune rheumatic disorders and seem to be suitable also for rare condition such as PM/DM (Andreoli et al., 2010; ; Doria et al., 2004; Kumar et al., 2010; Lockshin, 2006; Ruiz-Irastorza \& Khamashta, 2008, 2010; Saar et al., 2006; Váncsa et al., 2007).

The most important points to remember are summarized in table 3 and include the following (Doria et al., 2004; Lockshin, 2006; Ruiz-Irastorza \& Khamashta, 2008, 2010; Saar et al., 2006):

- $\quad$ every pregnancy in PM/DM should be regarded as a high-risk case, based on adverse fetal outcomes, maternal disease flares and drugs with potential teratogenic risk;

- all women should undergo counseling before conception, being informed for their specific risk to become pregnant (assess for risk factors, stratify risk as low/high, discuss potential adverse fetal effects); 
- appropriate pre-conceptional diagnostic procedures are obligatory, particularly if pregnancy related pathology has been detected previously; specific contraindications including severe organ dysfunction such as cardiopulmonary pathology should be identified, while full antibody profile should be assessed;

- pregnancies should be planned when myositis is in remission or is considered as low disease activity for a period of at least 3 to 6 months before pregnancy;

- women with a high-risk profile should be strictly monitored during gestation (visits should be more frequent as pregnancy advances, classically every 4 weeks until delivery) and postpartum (at least one visit 12 weeks thereafter) by a multidisciplinary team including rheumatologist, obstetrician and neonatologists is mandatory; uterine and umbilical artery Doppler and fetal echocardiography should be planned at every visit;

- adequate aggressive management (high doses corticosteroids and/or immunomodulators and immunosuppressors) should be recommended during flare-up and new-onset PM/DM as active disease can be more harmful for fetus than drugs and particularly severe prognosis is recognized.

\begin{tabular}{|c|c|}
\hline & Recommendation for myositis and pregnancy \\
\hline 1 & $\begin{array}{l}\text { Consider every pregnancy in PM/DM as a high-risk pregnancy } \\
\text { - adverse fetal outcomes } \\
\text { - maternal disease flare } \\
\text { - drugs with potential teratogenic risk }\end{array}$ \\
\hline 2 & Pre-pregnancy councelling of patients with myositis \\
\hline 3 & $\begin{array}{l}\text { Obligatory pre-conceptional diagnostic procedures } \\
\text { - diagnose severe organ dysfunction }\end{array}$ \\
\hline 4 & $\begin{array}{l}\text { Plan pregnancy in quiescent } \mathrm{PM} / \mathrm{DM} \\
\text { - inactive or remission disease }\end{array}$ \\
\hline 5 & $\begin{array}{l}\text { Monitor during gestation and postpartum } \\
\text { - } \quad \text { every } 4 \text { weeks until delivery and at least one visit } 12 \text { weeks in postpartum } \\
\text { - multidisciplinary team: rheumatologist-obstetrician-neonatologists }\end{array}$ \\
\hline 6 & $\begin{array}{l}\text { Indicate aggressive management during flare-up and new-onset PM/DM } \\
\text { - potential harmful for fetus than drugs and particularly severe prognosis is } \\
\text { recognized }\end{array}$ \\
\hline
\end{tabular}

Table 3. Recommendation for PM/DM pregnancy.

\section{Conclusions}

Pregnancy in women suffering from PM/DM is a rare event, requiring special attention since considered as a high-risk pregnancy. Adverse fetal outcome (fetal loss, premature delivery, intrauterine growth restriction, neonatal autoimmune disease), maternal disease flares or new-onset disease during gestation and the use of anti-rheumatic drugs with potential teratogenic risk are the mainstay to declare high-risk profile for myositis pregnant women. 
Furthermore, suitable pre-conceptional diagnostic proceedings and recognition of specific risk factors for unfavorable outcomes, close monitoring of disease activity and fetal prognosis with specific interdisciplinary (rheumatologist, obstetrician, neonate) intervention is mandatory.

Optimal pregnancy outcome can be anticipated in patients with pre-existing quiescent disease, while new-onset myositis and flare-up during pregnancy promotes significantly adverse pregnancy outcomes.

Finally, professional supervision warrants for a reliable pregnancy for the majority of women diagnosed with PM/DM.

\section{References}

Adams Waldorf, K.M. \& Nelson, L.J. (2008). Autoimmune disease during pregnancy and the microchimerism legacy of pregnancy. Immunol Invest, Vol.37, No.5, pp. 631-644, ISSN 0882-0139

Aleksza, M.; Szegedi, A., Antal-Szalma’s, P., Irinyi, P., Gergely, L., Ponyi, A., Hunyadi, J., Sipka, S., Zeher, M., Szegedi, G. \& Danko, K. (2005). Altered cytokine expression of peripheral blood lymphocytes in polymyositis and dermatomyositis. Ann Rheum Dis, Vol.64, pp. 1485-1489, ISSN (printed) 0003-4967

Andreoli, L.; Bazzani, C., Taraborelli, M., Reggia, R., Lojacono, A., Brucato, A., Meroni, P.L. \& Tincani, A. (2010). Pregnancy in autoimmune rheumatic diseases: The importance of counselling for old and new challenges. Autoimmunity Reviews, Vol.10, pp. 51-54, ISSN 1568-9972

Borchers, A.T.; Naguwa, S.M., Keen, C.L. \& Gershwin, M.E. (2010). The implications of autoimmunity and pregnancy. J Autoimmun (2010 May), Vol.34, No.3, pp. J287-J299, ISSN 0896-8411

Chopra, S.; Suri, V., Bagga, R., Thami, M.R., Sharma, A. \& Bambery, P. (2008). Autoimmune Inflammatory Myopathy in Pregnancy. Chopra et al, 2008 J Med, Vol.10, No.1, pp. 17, ISSN 1934-1997

Clowse, M.E.B. (2010). Managing contraception and pregnancy in the rheumatologic diseases. Best Practice E Research Clinical Rheumatology, Vol.24, pp. 373-385, ISSN: 1521-6942

Costa, M. \& Colia, D. (2008). Treating infertility in autoimmune patients. Rheumatology, Vol.47, pp. iii38-iii41, online ISSN 1462-0332, print ISSN 1462-0324

Cutulo, M.; Matucci-Cerinic, M., Lockshin, M. \& Østensen, M, (2008). Introduction: new trends in pregnancy and rheumatic diseases. Rheumatology, Vol.47, Suppl. No.3, pp. iii1-iii2, online ISSN 1462-0332, print ISSN 1462-0324

Cutolo, M.; Capellino, S. \& Straub, R.H. (2008). Oestrogens in rheumatic diseases: friend or foe?. Oxford Journals Medicine Rheumatology, Vol.47, Suppl No.3, pp. iii2-iii5, online ISSN 1462-0332, print ISSN 1462-0324

Doria, A.; Iaccarino, L., Ghirardello, A., Briani, C., Zampieri, S., Tarricone, E. \& Gambari, P.F. (2004). Pregnancy in rare autoimmune rheumatic diseases: UCTD, MCTD, myositis, systemic vasculitis and Beçhet disease. Lupus, Vol.13, No.9, pp. 690-5, online ISSN 1477-0962, print ISSN 0961-2033 
Doria, A.; Iaccarino, L., Ghirardello, A., Arienti, S., Zampieri, S., Rampudda, M.E., Tincani, A. \& Todesco, S. (2006). Rare autoimmune rheumatic illnesses during pregnancy. Systemic sclerosis, polymyositis /dermatomyositis and vasculitis. Z Rheumatol, Vol.65, No.3, pp. 200-208, ISSN 0340-1855

Gayed, M. \& Gordon C. (2007). Pregnancy and rheumatic diseases. Rheumatology, Vol.46, No.7, pp. 1634-1640, online ISSN 1462-0332, print ISSN 1462-0324

Gordon, C. (2004). Pregnancy and autoimmune diseases. Best Pract Res Clin Rheumatol (2004 Jun), Vol.18, No.3, pp. 359-379, ISSN 1521-6942

de Man, Y.A. \& Hazes, J.M.W. (updated March 2009). Pregnancy in rheumatic diseases: an overview. In: Oxford Textbook of Rheumatology (2004) 3rd edition, De Man \& Hazes, 2009, D.A., Woo, P., Glass, D. \& Breedveld, F.C, pp. 117-125, Oxford University Press, Oxford, UK

de Paepe, B.; Creus, K.K. \& de Bleecker, J.L. (2009). Role of cytokines and chemokines in idiopathic inflammatory myopathies. Curr Opin Rheumatol (2009 Nov), Vol.21, No.6, pp. 610-616, ISSN 1040-8711

Keeling, S.O. \& Oswald, A.E. (2009). Pregnancy and rheumatic disease: "by the book" or "by the doc". Clin Rheumatol, Vol.28, pp. 1-9, online ISSN 1434-9949, print ISSN 07703198

Kumar, S.; Suri, V. \& Wanchu, A. (2010). Pregnancy and rheumatic disorders. Indian Journal of Rheumatology (March 2010), Vol.5, No.1, pp. 35-41, ISSN 0973-3698.

Linardaki, G.; Cherouvim, E., Goni, G. \& Boki, K.A. (2011). Intravenous immunoglobulin treatment for pregnancy-associated Dermatomyositis. Rheumatol Int, Vol.31, pp. 113-115, ISSN: 0172-8172

Lockshin, M.D. (2006). Treating rheumatic diseases in pregnancy: dos and don'ts. Ann Rheum Dis, Vol.65, Suppl No.III, pp. iii58-iii60, ISSN (printed) 0003-4967

Märker-Hermann, E. \& Fischer-Betz, R. (2010). Rheumatic diseases and pregnancy. Curr Opin Obstet Gynecol (Dec 2010), Vol.22, No.6, pp. 458-65, ISSN 1040-872X, Online ISSN 1473-656X

Mecacci, F.; Pieralli, A., Bianchi, B. \& Paidas, M.J. (2007). The Impact of Autoimmune Disorders and Adverse Pregnancy Outcome. Seminars in Perinatology, Vol. 31, No.4, pp. 223-226, ISSN: 0146-0005

Motta, M.; Tincani, A., Meroni, P.L. \& Cimaz, R. (2008). Follow-up of children exposed antenatally to immunosuppressive drugs. Rheumatology, Vol.47, pp. iii32-iii34, online ISSN 1462-0332, print ISSN 1462-0324

Østensen, M. (2004). Disease specific problems related to drug therapy in pregnancy. Lupus. Vol.13, pp. 746-750, online ISSN: 1477-0962, print ISSN: 0961-2033

Østensen, M.; Förger, F., Nelson, J.L., Schuhmacher, A., Hebisch, G. \& Villiger, P.M. (2005). Pregnancy in patients with rheumatic disease: anti-inflammatory cytokines increase in pregnancy and decrease post partum. Ann Rheum Dis, 2005 June, Vol.64, No.6, pp. 839-844, ISSN (printed) 0003-4967

Østensen, M.; Lockshin, M., Doria, A., Valesini, G., Meroni, P., Gordon, C., Brucato, A. \& Tincani, A. (2008). Update on safety during pregnancy of biological agents and some immunosuppressive anti-rheumatic drugs. Rheumatology, Vol.47, Suppl. No.3, pp. iii28-iii31, online ISSN 1462-0332, print ISSN 1462-0324 
Østensen, M.; Brucato, A., Carp, H., Chambers, C., Dolhain, R.J.E.M., Doria, A., Förger, F., Gordon, C., Hahn, S., Khamashta, M., Lockshin, M.D., Matucci-Cerinic, M., Meroni, P., Nelson, J.L., Parke, A., Petri M., Raio, L., Ruiz-Irastorza, R., Silva et al., 2003 C.S., Tincani, A., Villiger, P.M., Wunder, D. \& Cutolo, M. (2011). Pregnancy and reproduction in autoimmune rheumatic diseases. Rheumatology, Vol.50, No.4, pp. 657-664 online ISSN 1462-0332, print ISSN 14620324

Pasrija, S.; Rana, R., Sardana, K. \& Trivedi, S.S. (2005). A case of autoimmune myopathy in pregnancy. Indian J Med Sci. (Mar 2005), Vol.59, No.3, pp. 109-112, ISSN 0019-5359

Peaceman, A. \& Ramsey-Goldman, R. (2008). Autoimmune Connective Tissue Disease in Pregnancy. Glob. libr. women's med., ISSN 1756-2228

Raghupathy, R. \& Kalinka, J. (2008). Cytokine imbalance in pregnancy complications and its modulation. Front Biosci, Vol.13, pp. 985-994, ISSN: 10934715

Ruiz-Irastorza, G. \& Khamashta, M.A. (2008). Lupus and pregnancy: ten questions and some answers. Lupus, Vol.17, pp. 416-420, Print ISSN 0961-2033, Online ISSN 14770962

Ruiz-Irastorza, G. \& Khamashta, M.A., American College of Rheumatology Patient Education Task Force. (2010). Pregnancy And Rheumatic Disease, updated Oct 2010, pp. 1-4

Saar, P.; Hermann, W. \& Iler-Ladner, M. (2006). Connective tissue diseases and pregnancy. Rheumatology, Vol.45, pp. iii30-iii32, online ISSN 1462-0332, print ISSN 14620324

Scott, J.R. (2002). Risks to the children born to mothers with autoimmune diseases. Lupus, Vol.11, pp. 655-660, Print ISSN 0961-2033, Online ISSN 14770962

Silva, C.A.; Sultan, S.M. \& De Man \& Hazes, 2009, D.A. (2003). Pregnancy outcome in adult-onset idiopathic inflammatory myopathy. Rheumatology (Oxford) (Oct 2003), Vol.42, No.10, pp. 1168-1172, online ISSN 1462-0332, print ISSN 14620324

Szodoray, P.; Alex, P., Knowlton, N., Centola, M., Dozmorov, I., Csipo, I., Nagy, A.T., Constantin, T., Ponyi, A., Nakken, B. \& Danko, K. (2010). Idiopathic inflammatory myopathies, signified by distinctive peripheral cytokines, chemokines and the TNF family members B-cell activating factor and a proliferation inducing ligand. Rheumatology (Oxford), oct 2010, Vol. 49, No.10, pp. 1867-1877, online ISSN 14620332, print ISSN 1462-0324

Tincani, A.; Nuzzo, M., Motta, M. \& Lojacono, A. (2006). Autoimmune diseases and pregnancy. Haematologica reports (September 2006), Vol. 2, No.10, pp. 56-60, ISSN: 1824-9337

Váncsa, A.; Ponyi, A., Constantin, T., Zeher, M. \& Dankó, K. (2007). Pregnancy outcome in idiopathic inflammatory myopathy. Rheumatol Int. (Mar 2007), Vol.27, No.5, pp. 435-439, ISSN: 0172-8172 
Zen, M.; Ghirardello, A., Iaccarino, L., Tonon, M., Campana, C., Arienti, S., Rampudda, M., Canova, M. \& Doria, A. (2010). Hormones, immune response, and pregnancy in healthy women and SLE patients. Swiss Med Wkly, Vol.140, No.13-14, pp. 187-201, ISSN: 1424-3997 


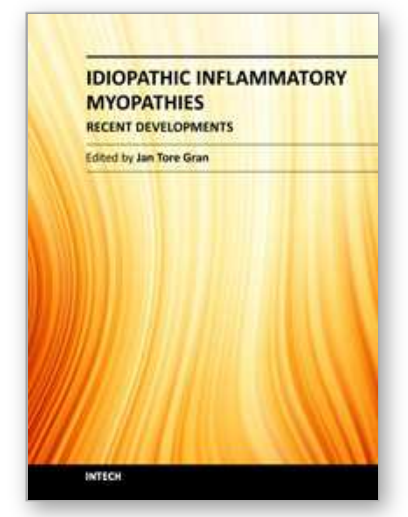

\author{
Idiopathic Inflammatory Myopathies - Recent Developments \\ Edited by Prof. Jan Tore Gran
}

ISBN 978-953-307-694-2

Hard cover, 212 pages

Publisher InTech

Published online 15, September, 2011

Published in print edition September, 2011

The term "myositis" covers a variety of disorders often designated "idiopathic inflammatory myopathies". Although they are rather rare compared to other rheumatic diseases, they often cause severe disability and not infrequently increased mortality. The additional involvement of important internal organs such as the heart and lungs, is not uncommon. Thus, there is a great need for a better understanding of the etiopathogenesis of myositis, which may lead to improved treatment and care for these patients. Major advances regarding research and medical treatment have been made during recent years. Of particular importance is the discovery of the Myositis specific autoantibodies, linking immunological and pathological profiles to distinct clinical disease entities. A wide range of aspects of myopathies is covered in the book presented by highly qualified authors, all internationally known for their expertice on inflammatory muscle diseases. The book covers diagnostic, pathological, immunological and therapeutic aspects of myositis.

\title{
How to reference
}

In order to correctly reference this scholarly work, feel free to copy and paste the following:

Codrina Mihaela Ancuta, Eugen Ancuta and Rodica Marieta Chirieac (2011). Pregnancy in Myositis: Challenges and Pitfalls, Idiopathic Inflammatory Myopathies - Recent Developments, Prof. Jan Tore Gran (Ed.), ISBN: 978-953-307-694-2, InTech, Available from: http://www.intechopen.com/books/idiopathicinflammatory-myopathies-recent-developments/pregnancy-in-myositis-challenges-and-pitfalls

\section{INTECH}

open science | open minds

\author{
InTech Europe \\ University Campus STeP Ri \\ Slavka Krautzeka 83/A \\ 51000 Rijeka, Croatia \\ Phone: +385 (51) 770447 \\ Fax: +385 (51) 686166 \\ www.intechopen.com
}

\author{
InTech China \\ Unit 405, Office Block, Hotel Equatorial Shanghai \\ No.65, Yan An Road (West), Shanghai, 200040, China \\ 中国上海市延安西路65号上海国际贵都大饭店办公楼 405 单元 \\ Phone: +86-21-62489820 \\ Fax: +86-21-62489821
}


(C) 2011 The Author(s). Licensee IntechOpen. This chapter is distributed under the terms of the Creative Commons Attribution-NonCommercialShareAlike-3.0 License, which permits use, distribution and reproduction for non-commercial purposes, provided the original is properly cited and derivative works building on this content are distributed under the same license. 